\title{
RESPONSIBLE DIVERSIFICATION: KNOWING ENOUGH ABOUT DIVERSIFICATION TO DO IT RESPONSIBLY: MOTIVES, MEASURES AND CONSEQUENCES
}

\author{
Ma. Belén Lozano García ${ }^{1}$ \\ Alberto de Miguel Hidalgo ${ }^{2}$ \\ Diana Monserrat Ríos Rodríguez.
}

\begin{abstract}
Diversifying in a responsible way is a challenge that many firms face today. In this survey we posit whether firms should diversify and whether it is a way to create value, since the motives leading to diversification are not always addressed to satisfying all stakeholders, and as a consequence the outcome may be different from the one expected. Our aim is to smooth the way for managers, shareholders, professionals and decision-makers in general by offering an exhaustive and rigorous description of the lessons provided by the literature, analyzing the reasons for diversifying or not, describing the costs and benefits of the process and analyzing the discount on firm value.
\end{abstract}

Key Words: value creation, diversification, discount, responsible strategic decision-making

JEL Codes: G0, M2, M21.

\section{Introduction}

For firms to be able to play an active role in meeting the challenges posed by aspiring to a more sustainable level of economic, social and environmental development, the decisions they make and the activities they carry out must be responsible and always take into account the best use of resources. In this sense, diversification is one of the most important and controversial strategic decisions a firm can make, and therefore it must be considered conscientiously. It is thus vital to examine this possibility in depth, since diversification is not always good for the firm, although on many occasions it is of course necessary to create value. Sometimes the motives leading to diversification are not addressed to satisfying the interests of all the stakeholders, and as a result its outcomes may not be satisfactory in all cases.

Many studies of the corporate diversification strategy have been carried out over the last three decades or so, not only in the area of corporate finance but also from the perspective of strategic management (Martin and Sayrak, 2003; Huerta and Navas, 2007; Benito, 2009; Wan, Hoskisson, Short and Yiu, 2011; Doaei, Ahmad and Adb, 2012; Benito, Guerras and Zuñiga, 2012). Findings have been diverse, with no consensus to date as to how to measure or conceptualize it. The diversification strategy can be understood variously as the expansion of the firm to new product markets, as the decisions that tend to broaden or diversify the firm's sphere of action, or as the increase in the number of industries in which the firm actively operates.

Moreover, a widely debated question is why firms diversify, since there is mixed empirical evidence as to the impact of diversification on firm value. Indeed, on the one hand there is evidence of a negative relation between a firm's value and its level of diversification. The evidence

\footnotetext{
${ }^{1}$ Universidad de Salamanca, Salamanca, Spain, e-mail: beloga@usal.es

${ }^{2}$ Universidad de Salamanca, Salamanca, Spain, e-mail: amiguel@usal.es

${ }^{3}$ Universidad Autónoma de Tamaulipas, Victoria, Spain,e-mail:drios@usal.es
} 
supporting this conclusion comes from different sources. For example, the fact that diversified firms have a lower Tobin's q than non-diversified firms, that they undergo a discount of approximately $15 \%$ with respect to the median of their industry, and that the market tends to react favourably to increases in business concentration (Weston, 1970; Lewellen, 1971; Chandler, 1977; Bemheim and Winston, 1990; Lang and Stulz, 1994; Berger and Ofek, 1995; Comment and Jarrell, 1995; Tirole, 1995; Rajan et al. 2000; Lamont and Polk, 2002).

On the other hand, there are studies that argue that the relation is positive, that is, that the diversification strategy does not destroy the value of the firms that decide to carry it out (Amihud and Lev, 1981; Stulz, 1990; Meyer et al. 1992; Chevalier, 1999; Matsusaka, 2001; Whited, 2001; Campa and Kedia, 2002; Graham et al. 2002; Gomes and Lividan, 2004; Mansi and Reeb, 2002; Villalonga, 2004a, 2004b; Santalo and Becerra, 2008).

Based on the results obtained in the literature, our aim is to offer some reflections on the situations in which firm diversification is appropriate, positing whether it is good for firms and society at large, or if, on the contrary, as a result of the outcomes obtained over many years, it is something that should be mitigated, in line with the theories that most strongly defend the discount obtained by firms that have undergone this course of action. To do so, we must identify the motives which lead firms diversify, the benefits and costs involved and whether or not value is created or destroyed in the process. Thus we also offer the set of business diversification measures - not yet agreed upon by consensus- in order subsequently to see what effect they have on firm value. This outline should provide some guidelines on corporate diversification for business professionals and facilitate decision-making in both the public and private spheres. To do so, the next section addresses the existing theoretical arguments as to why firms diversify, followed by a summary of the costs and benefits involved in the process. Subsequently, the measures most used for diversification are reviewed. Finally, we analyze the effect of this strategy on firm value.

\section{Review of the Literature \\ Why do firms diversify?}

The motives that lead firms to implement a diversification strategy have been the subject of many different and extensive studies which have led to different theoretical perspectives that currently justify this course of action.

From Neoclassical Theory, justification for diversifying can be found in the possibility that there will be economies of scope between the two productive functions. If the transaction costs foresee the existence of an efficient market in shared resources, economies of scope can lead to the emergence of multi-market firms. Seen from this perspective, corporate diversification would only make sense if directed at related or very similar products or markets. In the Industrial Economics approach, a diversification strategy would be justified by market power. Firms may diversify to increase their level of market power and hence the possibility of obtaining extraordinary performance.

From the point of view of New Economic Analysis there are two theories that justify the existence of a diversification strategy: Transaction Costs Theory and Agency Theory. In the former, diversification is justified on the basis that the organizational costs that occur in a diversified firm are lower than those of a specialized firm, whereas the latter approach predicts that managers will uphold a diversification strategy even though shareholder wealth decreases, as long as they can obtain benefits from the diversification that exceed the costs they incurred.

(Amihud and Lev, 1999; Denis and Thothadri, 1999). Thus, the financial literature has summarized the motives that lead managers to diversify as: an increase in compensations, power and prestige (Jensen, 1986); a reduction of the risk taken on by agents (Amihud and Lev, 1981); and entrenchment through investments that require their particular skills (Shleifer and Vishny, 1989), 
among others. In this approach, diversification is justified by the private benefits and personal preferences of the managers.

For its part, the Resource-Based Theory of the Firm is the dominant theory in Strategic Management (Barney, 1991; Villalonga and McGahan, 2005). This perspective posits that firms will diversify if they have an excess of resources and capabilities that are transferable among their industries and for which market imperfections exist. However, the strategic resources must be valuable, scarce, inimitable, and unsubstitutable (Barney, 1991). In Table 1 we present a summary of the theoretical trends that justify the diversification phenomenon.

Theoretical Approaches that Justify Diversification

Table no.1

\begin{tabular}{|c|c|c|c|}
\hline Approach & Theory & Justification & Authors \\
\hline \multirow[b]{2}{*}{ Economic } & Neoclassical Theory & Economies of scope & $\begin{array}{l}\text { Penrose, (1959); Teece } \\
\text { (1980); Panzar \& Willig } \\
(1981)\end{array}$ \\
\hline & $\begin{array}{l}\text { Theory of Industrial } \\
\text { Economics }\end{array}$ & $\begin{array}{l}\text { Market power } \\
\text { Economies of scale }\end{array}$ & $\begin{array}{lll}\text { Panzar } & \& & \text { Willing } \\
(1977) ; \quad S c o t t & (1982) ; \\
\text { Bernheim \& } & \text { Winston } \\
(1990) ; \text { Tirole } & \text { (1990); } \\
\text { Tirole (1995) } & \\
\end{array}$ \\
\hline \multirow[b]{2}{*}{$\begin{array}{l}\text { New } \\
\text { Economic } \\
\text { Analysis }\end{array}$} & Transaction-cost Theory & Organizational costs & $\begin{array}{ll}\text { Coase } & (1937) ; \\
\text { Williamson } & (1981) ; \\
\text { Milgrom \& } & \text { Roberts } \\
(1992,1993) & \\
\end{array}$ \\
\hline & Agency Theory & $\begin{array}{l}\text { Private benefits } \\
\text { Personal preferences } \\
\text { of managers }\end{array}$ & 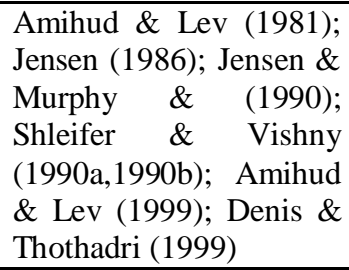 \\
\hline $\begin{array}{l}\text { Strategic } \\
\text { Management }\end{array}$ & Resource-Based Theory & $\begin{array}{l}\text { Excess resources and } \\
\text { capabilities }\end{array}$ & $\begin{array}{lr}\text { Penrose (1959); } & \text { Panzar } \\
\& \quad \text { Willing } & (1979) ; \\
\text { Wernerfelt } & (1984) ; \\
\text { Montgomery } & \& \\
\text { Wernerfelt } & (1988) ; \\
\text { Barney } & (1991) ; \\
\text { Villalonga \& } & \text { McGahan } \\
(2005) & \end{array}$ \\
\hline
\end{tabular}

Source: The authors

\section{Costs and benefits associated with corporate diversification}

As in many situations, making a strategic decision will lead to a series of consequences from which firms will obtain both costs and benefits. With diversification, benefits are obtained from the creation of internal capital markets, fiscal benefits, risk reduction or simply the advantages of economies of scale and scope (Chandler, 1977; Teece, 1980). On the other hand, the costs originate mainly from private managerial profits, although they can also derive from inefficient activity of internal capital markets and information asymmetries. Below we address all of these aspects.

The creation of internal capital markets allows a firm to allocate resources more efficiently among its different business units (Williamson, 1985), which can add value to the firm (Stein, 1997). A diversified firm can do this because it possesses more and better information about its 
investment opportunities and because the managers of the central office control the use of these resources by emulating the role of demanding shareholders with respect to the business units, thus reducing possible agency costs (Suárez, 1994).

Furthermore, the diversification strategy is associated with obtaining tax benefits owing to the coinsurance effect (Lewellen, 1971), a result of operating business units with imperfectly correlated cash flows, giving the firm a larger capacity for debt in comparison to non-diversified firms of similar size. In this way, debt capacity creates value by increasing the tax deductions on interest. In contrast, non-diversified firms find themselves at a significant fiscal disadvantage because when they obtain profits they pay taxes to the government, whereas the government does not pay the firm when the firm registers losses (Majd and Myers, 1987). Diversified firms can also make fiscal savings immediately by compensating the losses on some segments with the gains in others (Berger and Ofek, 1995).

Another benefit associated with diversification has to do with risk. By participating in more than one industry, diversified firms can reduce their non-systematic risk associated with participating in only one business (Lewellen, 1971; Comment and Jarrell, 1995). The larger the number of businesses in which the firm operates that are little or negatively correlated, the greater the potential of diluting the risk of each of the businesses (Chang and Thomas, 1989). Likewise, firms participating in more than one business can grow by obtaining the advantage of economies of scale and scope (Chandler, 1977; Teece, 1980).

In contrast, the potential costs of diversification stem mainly from agency problems: from the intention of managers to increase their private benefits at the expense of shareholder wealth (Jensen, 1986; Morck, Shleifer and Vishny, 1990), increase their compensation, power and prestige (Korahna and Zenner, 1998), or reduce their personal risk. Thus, conglomerates provide a good opportunity for firm managers with free cash flow to make investments with current negative net value (Jensen, 1986) or to entrench themselves by managing diversification in a way that coincides with their own professional skills (Shleifer and Vishny, 1989). In this same line Denis, Denis and Sarin (1997) conclude that agency costs are associated with the decision to diversify.

Internal capital markets may also operate inefficiently owing to cross-subsidies among the divisions. Firms tend to overinvest in segments with poor investment opportunities, subsidizing them through the other business units with more opportunities for profit (Berger and Ofek, 1995; Meyer et al. 1992). Another reason for internal market inefficiency is the internal rivalry generated by the allocation of resources among the divisions of a diversified company (Scharfstein and Stein, 2000; Rajan, Servaes and Zingales, 2000) or investment in business lines with poor investment opportunities (Stulz, 1990). Some scholars, such as Shin and Stulz (1998), studied the efficiency of internal capital markets and concluded that, on average, they are inefficient.

Finally, another cost of diversification is that deriving from the information asymmetries that arise between central management and divisional mangers (Harris, Kriebel and Raviv, 1982), or between executives and external investors (Stein, 1997; Fluck and Lynch, 1999; Hadlock et al. 2001).

The next step that should concern all firm managers is to weigh the costs and benefits that the diversification decision will involve, the result of which will give rise either to a discount or a premium on the corporate value. Thus in the next section we address how to measure diversification in order subsequently to analyze its effect on firm value. As we shall see, it is a task that does not provide a clear answer, nor can it be resolved immediately.

\section{A pitfall to be overcome: the lack of consensus regarding how to measure diversification}

How can we measure the diversification of a firm? No consensus could be found in the literature on corporate diversification with regard to what measures should be used. In fact, Rumelt 
(1974) argues that neither the definition nor the measures of diversification have been generally accepted. The decision to measure the degree and/or type of diversification has important implications when studying the relation between diversification and firm value. There is empirical evidence that the "methodology" employed in the study of this relationship can influence the results obtained. (Palepu, 1985: 239; Ramanujam and Varadarajan, 1989). This has led many researchers increasingly to combine continuous and categorical measures in order to overcome their respective weak points. However, as shown in the results obtained by Hall and John (1994), this course of action must be used with caution, since it is not the most appropriate way to surmount the limitations of either type of measure. We now turn to analyze the types of measures most commonly used in research studies on diversification: continuous measures developed from an industrial classification system (SIC classifications), and categorical measures, commonly called typologies.

The continuous measures emerged from the literature in the field of industrial economics and are considered more objective (Montgomery, 1982; Pitts and Hopkins, 1982), whereas the typology measures offer a more enriched and complex view of diversification (Rumelt, 1974). We begin by analyzing continuous measures to then move on to the measures based on typologies and measures of efficient diversification.

\section{Continuous Measures}

This type of measure has generally been employed in the fields of industrial economics (Palepu, 1985) and finance, the first quantitative analysis of diversification in industry having been made by Gort (1962) for American industry using the first diversification index based on the socalled primary product specialization ratio $(P P S R)^{4}$. The principal disadvantage of using this rather simplistic measure is that it does not consider the proportion of each of the businesses or products in which the firm is involved, and therefore it exaggerates a firm's actual degree of diversification.

Owing to the limitations of this measure, more complex indexes have been developed that reflect the size of a firm's different businesses. These indexes are based on the pioneering work of Hirschman (1945) $)^{5}$ and Herfindahl (1950). Basically, we are referring to the indexes proposed by Berry (1971), which is a modification of the Hirschman-Herfindahl index and the entropy index (Palepu, 1985).

The first index is the one proposed by Berry (1971):

$$
D=1-\sum_{i=1}^{n} P_{i}^{2}
$$

Where $\mathrm{D}$ is the diversification index, $\mathrm{n}$ is the number of digits $(2-, 3-$, or 4$)$ in the SIC code in which the firm is currently active, and $\mathrm{Pi}$ is the ratio of sales in each SIC code to total firm sales.

The second index, the entropy index, was originally developed by Jacquemin and Berry (1979) and subsequently extended by Palepu (1985). It is based on three elements involved in the diversity of a firm's operations: 1) the number of product segments in which the firm operates; 2) the distribution of total sales through product segments, and 3) the degree of the relation among the different product segments (Palepu, 1985).

What actually distinguishes this measure from the other is the joining of these elements. It enables the total diversity of a firm to be broken down into two additional elements: a) an unrelated

\footnotetext{
${ }^{4}$ The degree of diversification can be expressed as: GD $=\sum s j=1-\mathrm{REP}$. Where $s j$ is the percentage of the $j$-ths secondary products within the firm whose diversification is being measured .

${ }^{5}$ There is debate as to the correct name of the concentration index - best known as the Herfindahl index- because Hirschman claimed the authorship of that index in his note of 1964.
} 
component that measures the degree to which the outputs are distributed in products through the groups of unrelated industries (URE), and b) a related component, which measures the output distribution among products that are related within the groups of industries (RE).

Below we show the Total Entropy Index:

$$
T E=\sum_{i=1}^{n} P_{i} \ln \left(1 / P_{i}\right)
$$

Where Pi is the proportion of a firm's total sales in the ith industry segment (Palepu, 1985; Hall and John, 1994; Markides and Williamson, 1996), that is, the ratio of sales in the ith segment to total firm sales, and where $\mathrm{n}$ is the number of industry segments in which the firm participates. In this approach, "industry segments" refer to groupings at the 4-digit level of the industrial classification system (Hall and John, 1994). Thus, the Total Entropy index (TE) is a weighted average of the firm's participation in the segments or the firms' different activities. One of the principal characteristics of the entropy index is that it recognizes the degree of the relationship among the segments in which the firm participates. Thus, a group of industries is defined as a set of related segments, such that REj is the related diversification of several segments within a industry group $\mathrm{j}$ (Palepu, 1985). Diversity is therefore measured within industryr groups (Hall and John, 1994) and can be expressed as follows:

$$
R E_{j}=\sum_{i=j}^{M} P_{i}^{j} \ln \left(1 / P_{i}^{j}\right)
$$

where Pij is the percentage of the ith segment of the jth group in the total sales of the group and $\mathrm{M}$ is the number of groups of industries in which the $n$ segments are found. Therefore, $n \geq M$ as a function of the first two digits of the industrial classification system code. In this way, if a firm participates in several groups of industries its Total Related Entropy can be expressed as follows:

$$
R E=\sum_{j=1}^{M} T E_{j} P^{j}
$$

Where $\mathrm{Pj}$ is the ratio of sales of the jth group to the firm's total sales. In contrast, the Unrelated Entropy Index (URE) measures a firm's activity in different groups of industries. It is defined in the following way:

$$
\mathrm{URE}=\sum_{j=1}^{M} P^{i} \ln \left(1 / P^{i}\right)
$$

Where $\mathrm{Pj}$ is the ratio of the firm's total sales to the jth industry group, and $\mathrm{M}$ is the number of groups of industries (Hall and John, 1994).

In short, the entropy measure yields three indexes for each firm: a) the Related Entropy Index (RE), b) the Unrelated Entropy Index (URE), and c) the total entropy or Total Diversification Index (TE). It expression is:

$$
T E=R E+U R E
$$

The main difference between these two measures of diversification is that the Herfindahl Index (Berry, 1971) assigns a smaller weight to small businesses. However, the Entropy index is better than the Herfindahl in that it not only provides a diversification index but is also able to break down the total diversification, identifying its direction towards related or non-related businesses. Moreover, the Entropy Index has a reasonably strong validity as a measure of diversification (Hoskisson et al., 1993).

Finally, the last measure is the one proposed by Varadarajan and Ramanujan (1987), a categorization named broad-spectrum diversity (BSD) and narrow-spectrum diversity (NSD). The purpose of this measure is to conceptualize two dimensions for measuring business diversification 
and is based mainly on the work of Berry (1971) and Wood (1971). The principal change can be found in narrow-spectrum diversity (NSD). In this measure the four-digit number in the industrial classification code is changed to a two-digit one and is called "mean narrow-spectrum diversity"(MNSD). Figure 1 shows the matrix resulting from this conceptualization: each cell of the matrix represents the total number of a firm's prior diversification activities is various industries two-digit and four-digit categories of the industrial classification system.

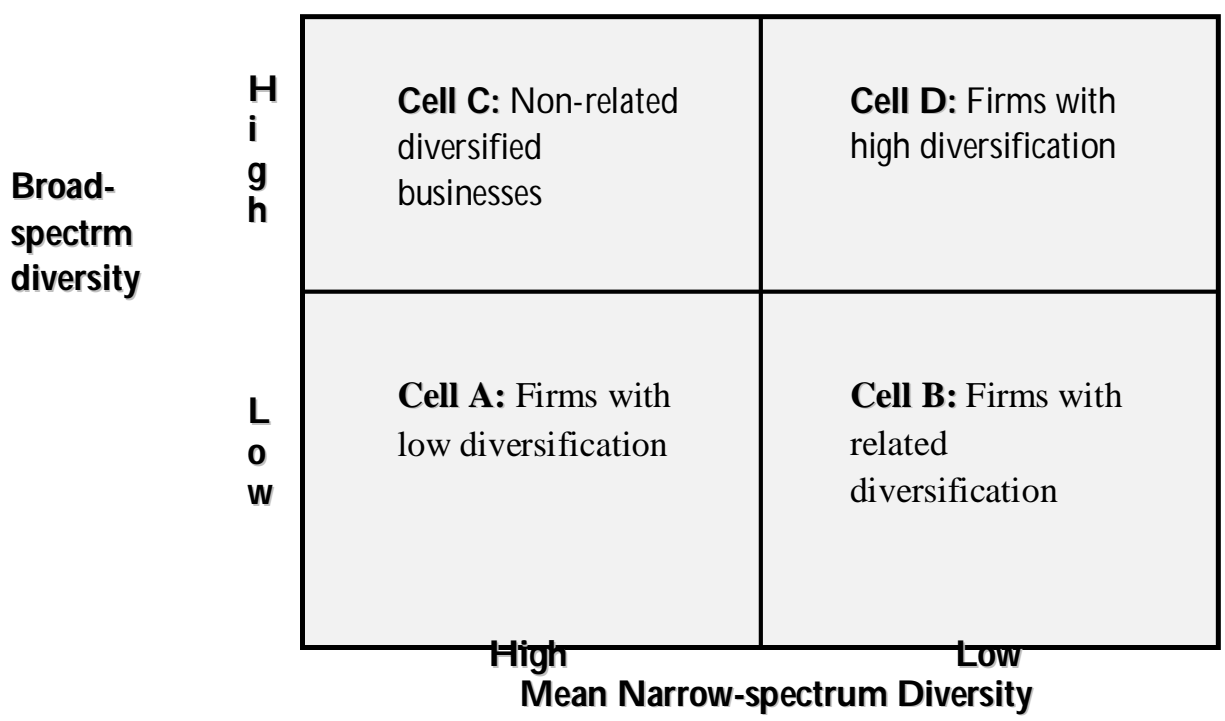

Figure no. 1. - Conceptualization of Firm Diversity Source: Varadarajan and Ramanujan $(1987,383)$

The definition of each spectrum is described in detail below:

Broad-spectrum diversity (BSD): the number of two-digit categories of the industrial classification system in which the firm is active.

Mean narrow-spectrum diversity (MNSD): the number of four-digit categories of the industrial classification system in which the firm is active, divided by the number of two-digit categories in which the firm operates.

In favour of this measure is the fact that it does not require information on business segment sales, and yet still provides an overall view of both the degree of diversification, high versus low, and the firm's predominant direction towards related or unrelated businesses (Varadarajan and Ramanujan, 1987).

To summarize, among the main advantages of the continuous measures based on SIC codes is that fact that they are easy to operationalize and use and that they are objective, to which we should add that they also require less effort and time to apply. Their mathematical property of continuity allows differences in diversity to be identified and measured adequately both betweenfirm and over time. Another advantage is that they also permit the replication and comparison of results found by different researchers. Their limitations derive above all from the fact that the great majority are based on data from the SIC code. This characteristic, which on the one hand guarantees the objectivity of the measure, on the other does not permit adequate differentiation of the different business segments or enable us to determine the nature of the diversified firm (Pitts and Hopkins, 1982; Palepu, 1985); moreover, the distance between the SIC codes cannot be measured by a ratio or scale of intervals (Nayyar, 1992). 


\section{Measures based on typologies}

Categorical measures were developed by specialists in the area of business strategy, are qualitative in nature, and furthermore allow us to distinguish the type of diversification strategy (Suárez and González, 1994). They are subjective typologies that attempt to capture not only the degree of a firm's diversification but also the type of relations existing among its business units.

There are several studies that propose typology-based measures of diversification, but it is undoubtedly the pioneering work of Rumelt (1974), based on work developed originally by Wrigley (1970), that is most used in practice. Rumelt classifies firms into four types of diversification categories based on the original classification proposed by Wrigley (1970):

a) Single Business (SB): Rs $\geq 95 \%$

b) Dominant Business (DB): $70 \% \leq \mathrm{Rs} \geq 95 \%$

c) Related Business (RB): $\mathrm{Rs}<70 \%$ and $\mathrm{Rr} \geq 70 \%$

d) Unrelated Business (URB): Rs $<70 \%$ and $\mathrm{Rr}<70 \%$

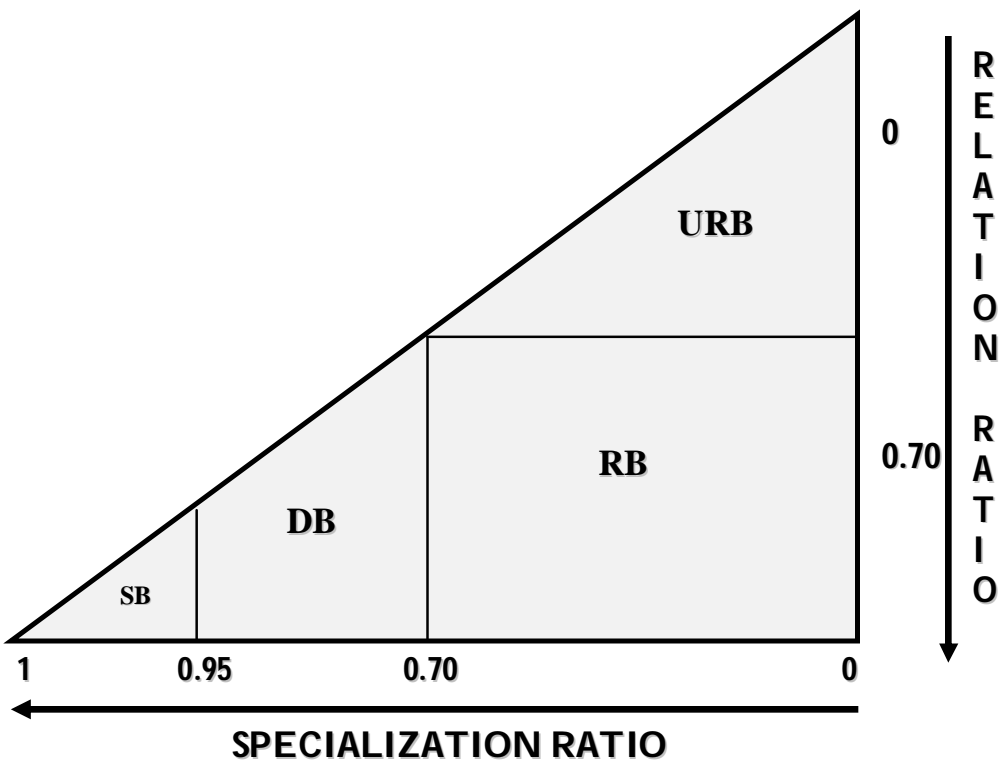

Figure 2: Strategic Categories of Wrigley/Rumelt Source: Rumelt $(1974,31)$

Rumelt (1974) also defines two ratios besides the one proposed by Wrigley (1970) -the Specialization Ratio (Rs) - (see Figure 2), which is the proportion of total firm sales attributed to the firm's largest single business, and the Related Ratio (Rr) which shows the proportion of a firm's annual sales corresponding to its largest group of related business. Finally, the Vertical Ratio (Rv) is the proportion of the firm's annual sales of all intermediate and final products of a chain of activities vertically integrated within one production process.

Rumelt's work was able to overcome the limitations of the measures based on SIC codes with respect to identifying the nature of the diversification strategy by taking into consideration not only productive relations but also those that may exist in areas such as marketing and research and development $(\mathrm{R}+\mathrm{D})$. However, it has evident disadvantages, relating mainly to the classification process, since it requires judgements on the part of the researcher both to define what the firm's businesses are and the degree of relatedness or proximity between them. Also, the decision to distinguish between diversified and non-diversified firms based on whether their specialization ratio is above or below $70 \%$ is a further weakness since its choice is not supported by any technical argument. 


\section{Measures of Efficient Diversification}

One of the most important objectives of the diversification strategy from the perspective of the financial literature is a firm's investment in different projects with a view to eliminating nonsystematic or specific risk. In this sense, the risk to be concerned about is the kind that cannot be eliminated by diversification; that is, systematic risk that in conditions of equilibrium shows a straight line with the level of profitability needed.

The main point of efficient diversification measures is that they capture the sensitivity of a business's profitability in relation to the profitability of a market portfolio. In these measures, whether or not the firms are diversified is not identified a priori; estimations are made using the profitability and risk data to obtain a portfolio of optimum industries or projects in order to subsequently assess the degree of efficient diversification, that is, the degree at which nonsystematic risk has been eliminated. This means that, for a determined level of risk, a firm that has reached its level of efficient diversification (or is close to it) will have maximum profitability in equilibrium. Introducing systematic risk as a point of reference in profitability is essential and efficient diversification is the measure that determines the best profitability-risk ratio.

Thus, firms with a non-efficient level of diversification would show less profitability in the face of a certain level of risk, or, alternatively, greater risk for a certain level of profitability. Hence, efficient diversification is configured as a measure that implicitly incorporates the profitability-risk goal that the firm should pursue.

Although these models were developed to be applied to capital markets and not real markets, it must be kept in mind that firms' ability to generate profits and their risks do not derive from their participation in capital markets, but rather their presence in real markets. These measures are generally based on applications of the portfolio selection model, the capital asset pricing model and the market model (Markowitz, 1952, Sharpe, 1964, Barnea and Logue, 1973), and take into account the assumptions of relative market perfection, combining product and market diversification. The aim of these measures is to determine the most appropriate sectoral categories to invest in and the optimum amount to be invested.

The approach to efficient diversification made by Smith and Schreiner (1969) is an ex-ante model based mainly on the portfolio selection theory (Markowitz, 1952), but instead of selecting shares of companies, they select the industries considered optimum for market investment. To this end, Smith and Schreiner (1969) define the conglomerate as a firm that invests capital in several sectoral categories and emphasizes external growth (fusions and acquisitions) over internal growth.

The efficient diversification measure proposed by these authors is derived from the Sharpe Index (1966).

$$
D^{*}=\frac{E\left(P^{*}\right)-E\left(P^{*}\right)}{S\left(P^{*}\right)}
$$

Where $\mathrm{D}^{*}$ is the efficient diversification index, $\mathrm{E}\left(\mathrm{P}^{*}\right)$ is the expected firm profitability, $\mathrm{E}\left(\mathrm{P}^{\mathrm{o}}\right)$ is the profitability expected from a risk-free asset, and $\mathrm{S}\left(\mathrm{P}^{*}\right)$ is the standard deviation of expected firm profitability.

This measure of efficient diversification concentrates only on one dimension of conglomerate activity: its capability to invest in an appropriate group of sectoral categories. However, it does not include important variables such as the direction or the potential economies of scale (Smith and Schreiner, 1969).

In parallel, another measure of diversification is the one proposed by Barnea and Logue (1973), who try to add a perspective to the problem of diversification measures by identifying a measure that is easy to calculate and that, considering the assumptions of relatively perfect capital markets, contains both product elements and market diversification elements. The authors start from the market model: 


$$
R_{i t}=\alpha+\beta_{i} R_{m t}+\varepsilon_{i t}
$$

Where Rit is the profitability of firm i in period t, $\mathrm{R} m t$ is the market profitability in period $\mathrm{t}, \beta i$ is the systematic risk and eit is the random disturbance.

The authors propose as potentially useful measures of diversification the determination coefficient $\mathrm{R}^{2}$ (the proportion of variance in portfolio earnings explained by the systematic risk component) and the standard error of the estimation or the standard deviation of the residuals, $\sigma(\varepsilon)$.

As diversification measures, $\mathrm{R}^{2}$ and $\sigma(\varepsilon)$ can be considered superior to all the commonly used physical measures of diversification because they are theoretically sensitive to interdependencies, and are unequivocal and relatively objective and comprehensive, that is, they incorporate both product and market diversification. If the objective of the research is the diversification of risk, both measures are superior to the most commonly used ones (Barnea and Logue, 1973). However, $\mathrm{R}^{2}$ provides a more intuitive numerical meaning for the estimation of diversification as its measuring scale ranges from 0 to 1 .

In short, the advantages of efficient diversification measures are mainly that they take market behaviour into consideration, are objective, and take into account both the expected earnings and a risk measure. Also important is the fact that it is not necessary to make a priori judgements about the definition of what a diversified firm is or is not, since starting from the advantage of diversification (the elimination of non-systematic risk) it can be concluded whether firms are or are not implementing a diversification strategy that will help them to eliminate risk, measured by the $\beta$ or its standard deviation. These measures can become an additional tool for the management of diversified firms. Their principal disadvantage is that to be developed they have to be based on restricted assumptions. One of the criticisms is that these assumptions are not adapted to the real world; however, it should be taken into account that a model should not be judged by the realism of its assumptions but rather the realism of its predictions (Blume, 1971). Finally it must be noted that with these measures it is not possible to identify the type of diversification. Table 2 presents a summary of the diversification measures grouped by categories, and by continuous, categorical and efficient measures.

The different approaches used to measure the variables, i.e. the different ways of approaching the measurement of diversification, condition the results mainly because they capture different aspects of company diversification. Ultimately, we must understand that diversification is a construct too complex to be captured by general diversification measures (Benedict, 2009). In this sense, it is necessary to determine the effect of diversification on the value of companies and how managers can evaluate different scenarios to make the best decision that will maximize shareholder value. 
Summary of Diversification Measures

Table no. 2

\begin{tabular}{|c|c|c|c|c|}
\hline Type & Measure & Strength & Weakness & Author \\
\hline \multirow{3}{*}{ Continuous } & Berry-Herfindahl Index & - Easy-to-calculate index & $\begin{array}{l}\text { - Provides only the degree of } \\
\text { diversification, but not its direction: } \\
\text { related or unrelated. }\end{array}$ & Berry (1971) \\
\hline & Entropy Index & $\begin{array}{l}\text { - Captures diversity through groups of products } \\
\text { (related) and within groups of products } \\
\text { (unrelated). Provides the degree of total } \\
\text { diversification and its components: } \\
\text { - Related Businesses (RB), - Unrelated } \\
\text { Businesses (URB) }\end{array}$ & $\begin{array}{l}\text { - Requires sales revenue data at the } \\
\text { 4-digit level. } \\
\text { - Complex calculation }\end{array}$ & Palepu (1985) \\
\hline & $\begin{array}{l}\text { Broad- or Narrow- } \\
\text { spectrum Diversity }\end{array}$ & $\begin{array}{l}\text { - Simplicity } \\
\text { - Easy to measure and calculate }\end{array}$ & $\begin{array}{l}\text { - Questionable validity and } \\
\text { reliability }\end{array}$ & $\begin{array}{l}\text { Varadarajan \& } \\
\text { Ramanujan (1987) }\end{array}$ \\
\hline Categorical & $\begin{array}{l}\text { Wrigley/Rumelt } \\
\text { Classification }\end{array}$ & $\begin{array}{l}\text { - Conceptual rigor } \\
\text { - Considers both the firm's history and } \\
\text { behaviour in order to determine the use of its } \\
\text { strengths, essential capabilities and its } \\
\text { diversification goals. }\end{array}$ & $\begin{array}{l}\text { - Subjectivity of the measure } \\
\text { - Questionable reliability } \\
\text { - Time-consuming analysis } \\
\text { - Requires excessive information on } \\
\text { the firm, thus necessitating several } \\
\text { sources of information. }\end{array}$ & $\begin{array}{l}\text { Wrigley (1970); } \\
\text { Rumelt (1974) }\end{array}$ \\
\hline \multirow[t]{2}{*}{ Efficient } & \multirow[t]{2}{*}{ Based on Sharpe (1966) } & $\begin{array}{l}\text { - Easy to calculate } \\
\text { - Concentration of the conglomerate's skills to } \\
\text { invest in an appropriate group of sectoral } \\
\text { categories. }\end{array}$ & $\begin{array}{l}\text { - Only provides an optimum level } \\
\text { of diversification, but not its } \\
\text { direction (related or unrelated). } \\
\text { - Does not include variables such as } \\
\text { economies of scale. }\end{array}$ & $\begin{array}{l}\text { Smith \& Schreiner } \\
\text { (1969) }\end{array}$ \\
\hline & & $\begin{array}{l}\text { - Objective } \\
\text { - Considers market assumptions and a measure } \\
\text { of risk. }\end{array}$ & $\begin{array}{l}\text { - Restrictive starting assumptions } \\
\text { are needed. } \\
\text { - Does not provide the direction of } \\
\text { the diversification }\end{array}$ & $\begin{array}{l}\text { Barnea \& Logue, } \\
\text { (1973) }\end{array}$ \\
\hline
\end{tabular}

Source: Adapted from Sambharva (2000: 165) 


\section{The Debate: Does diversification create or destroy wealth?}

Managers are required to make strategic decisions that will result in growth of the company, either from the core business of the company - organic growth, or through the acquisition of other companies in its sector or other industries - inorganic growth. For this reason market information will allow them to gain valuable data to build their strategy. In this sense, the diversification strategy has become an accurate way to conduct business growth. However, its effect on the value of companies is unclear. Currently, it is not only necessary to understand the existence or nonexistence of a discount, but also the reason why this phenomenon appears in some companies but not in others.

Empirical studies investigating the effect of a diversification strategy on firm value posit, on the one hand, a strategy that destroys value, and on the other, a strategy that creates value for the firm. There are many studies that support the existence of a discount associated with diversification. Lins and Servaes (2002) found discounts caused by diversification in Japan (10\%) and in the UK (15\%) similar to those found by Berger and Ofek (1995); however, in the case of Germany no evidence of a discount was found. Lang and Stulz (1994) did not find evidence of a positive relation between diversification and firm value; in their study they compare the Tobin's q of non-diversified forms with the imputed Tobin's q of the segments of diversified firms.

However, they also found in their study that firms finally diversify and negotiate their shares at a discount even before diversifying. For their part, Berger and Ofek (1995) identified the potential sources of value destruction in diversified firms by studying a sample of diversified and non-diversified firms for the period 1986-1991. They measure firm value as the logarithm of the ratio of total firm value to the sum of the imputed value of its segments, considering the latter as independent entities. They conclude that there is a negative and significant relation of between $13 \%$ and $15 \%$ for diversified firms, and this loss is robust to the inclusion of different measures of firm value and diversification.

The inefficiency of internal capital markets in diversified firms also supports the hypothesis of value destruction in this sense. Lamont (1997) studied a sample of oil companies and found significant evidence of internal capital markets. For their part, Shin and Stulz (1998) found evidence for the idea that internal capital markets are inefficient on average. Rajan et al. (2000) examined a sample for the 1979-1993 period and found that on average the industry-adjusted Tobin's q for diversified firms is significantly lower than that of specialized firms. Lamont and Polk (2002) argue that the exogenous variation in diversification is necessary in order to make inferences about the causal effect. These authors conclude that the exogenous changes are negatively related to firm value due to changes in industry investment and they interpret this fact as evidence of value destruction caused by diversification. Rivalry among the different business units of a firm to receive a larger allocation of the resources is another potential cause of the inefficiency of internal capital markets (Scharfstein and Stein, 2000). Despite the ample evidence proposed to support the internal capital market hypothesis, Whited (2001) found that there were measurement error problems in the method common to all the studies, which once corrected leads to a rejection of this hypothesis. Chevalier (2000) analyzed a sample of merged firms and found that the investment models attributed to inefficient investments were present in the firms prior to the merger.

But the outcomes of diversification are not always negative. There are also works that have found that the diversification strategy does not destroy firm value and that the discount these firms encounter may be the spurious result of measurement errors and of the endogeneity of the sample selection. Indeed, the diversification discount may be the spurious result of measurement errors of the segments of diversified firms. Villalonga (2004a) analysed a sample of US firms for the 19891996 period by constructing business units that are consistently defined through the firms. Her results reveal three main problems with respect to the use of data at the segment level. First, the 
level of disaggregation of the segments appearing in the financial reports is much lower than the firms' real level of diversification (Lichtenberg, 1992). In this sense, Villalonga corroborates that the data sources that permit firms to report on the number of total segments in which they are active can surpass by far the classic restriction of 10 segments $^{6}$. In the US economy, 56\% of the top 500 quoted companies (Montgomery, 1994) and 17\% of all the firms on COMPUSTAT (Lichtenberg, 1992) participate in more than 10 industries. Secondly, the very definition of "segment" can lead to the aggregation of two or more related or unrelated activities. Davis and Duhaime (1992) argue that in $5 \%$ to $10 \%$ of the cases analyzed, the businesses are grouped into a single segment that is neither related nor vertically integrated. Thirdly, firms frequently report a change in the segments in which they are active when actually this change never took place. The findings of Denis et. al. (1997) support the existence of this problem; approximately one-fourth of the changes in segments reported by the firms in COMPUSTAT never actually took place. Villalonga (2004a) concludes that firms obtain an average premium for diversification of 0.28 using data from BITS ${ }^{7}$, whereas with COMPUSTAT the results yield an average discount of 0.18 . Therefore, the effect of diversification is contingent upon the data source used, and the more consistent and objective the definition of the units or segments of diversified firms, the more likely the "diversification discount" can be reversed.

The diversification discount can also be the result of errors in measurement involved in taking a portfolio of businesses of a single segment as a reference in order to compare the market value of diversified and non-diversified firms. Graham et. al. (2002) provide favourable evidence in this respect when analyzing a sample comprising firms that expanded through acquisition and/or increased their number of business segments for the period from 1978 to 1995 . These authors show that a large part of the reduction in excess value takes place because firms acquire business units that were already trading at a discount and not because the diversification strategy in itself destroys value. It is worth noting, therefore, that their findings imply that the supposed standard that businesses comprising only one segment are the best units to use for making comparisons with diversified firms must be carefully reconsidered.

Another possible cause of the diversification discount comes from not taking the endogeneity of the diversification decision into account. According to this argument, it is not diversification that causes the discount, but rather that non-diversified businesses facing adverse conditions in their industry may diversify as the best response to these conditions. Campa and Kedia (2002) studied a sample of diversified and non-diversified firms for the 1978-1996 period and controlled for endogeneity. Their results show a strong correlation between a firm's decision to diversify and its value, and using this method the diversification discount disappears and in some cases even turns into a premium. In this same vein we have the results obtained by Matsusaka (2001). The central idea of his study is that firms consist of organizational capabilities that can be beneficial in many different kinds of businesses and that diversification is a search process through which firms seek businesses that are a good match for its capabilities. The findings of Villalonga (2004b), who used econometric methods that consider causal inference, show that, on average, diversified firms do not undergo a reduction in their value. These conclusions are robust to the choice of estimator, sample, and measures of excess value utilized.

What about the positive side? Under what circumstances can we support the hypothesis that diversification creates value? It is undisputed that at present a large number of companies continue to diversify, either through mergers, acquisitions or the internal development of new product lines. Regardless of form, the diversification phenomenon remains an important practice in the current business situation, and therefore subject to great academic interest.

\footnotetext{
${ }^{6}$ A limitation imposed on US firms by the Financial Accounting Standards Board (FASB).

${ }^{7}$ Business Information Tracking Series: a database on the US economy.
} 
In order to find answers to this phenomenon it is necessary to consider that a single theory cannot fully explain the complex phenomenon of diversification. Even though it must be admitted that the main theory in the area of finance scholarship, the Agency Theory, has helped to achieve significant conclusions about the motivation of diversification, it is also necessary to add new approaches and theories that complement and help to clarify the phenomenon of the diversification strategy. Under the above scenario, a new line of research has been added to the extensive literature on diversification, providing evidence of an effect of a diversification strategy on firm value. In other words, a broader and more dynamic conception of this relationship, in which this strategy can in some cases result in a discount while in others it can create value (Matsusaka, 2001; Bernardo and Chowdhry, 2002; Khoroshilov and Dodonova, 2005; Burch, Nanda, and Narayanan, 2003; Gomes and Lividan, 2004; Mackey, 2006; Santalo and Becerra, 2006; Hund, Monk and Tice, 2007, 2010, 2012; Santalo and Becerra, 2008; Kuppuswamy, Serafeim, andVillalonga, 2012). Specifically, the proposal of these studies can be summarized in that it is not appropriate to speak of a general effect, either positive or negative, of diversification on firm value (Zhao, 2008). Also, these new approaches allow us to observe that there is no universally valid nature of the relationship between diversification strategy and firm value (Bausch and Pils, 2009).

Built on the arguments of the benefits of diversification, this literature takes a dynamic perspective on the organizational structure of the company. According to this line of scholarship, managers can employ strategies of diversification to abandon relatively unproductive and unprofitable business lines in order to move into business in alternative sectors to provide better opportunities for growth (Matsusaka, 2001; Khoroshilov and Dodonova, 2005; Burch, Nanda, and Narayanan, 2003; Gomes and Lividan, 2004). Similarly, there is little probability that there exists an optimal level of diversification that is common to all sectors, due to sectoral heterogeneity (Santalo and Becerra, 2008). Research in this line supports the consideration of Stein (1999), when he states that the average value of the diversification discount is not the most informative item of the impact of diversification strategy on firm value.

New trends in explaining the diversification discount argue that not only should economic and financial variables be considered in explaining the diversification-value ratio, but also factors such as the organizational capacity, sectoral heterogeneity, growth options and age of the company. From the resource-based theory, firms are shaped by organizational capabilities -particularly the skills and competencies of high- and mid-level managers- that can be profitable in multiple businesses (Chandler, 1990). More specifically, organizational skills may range from marketing distribution abilities to skills in product development to organizational skills. That is, general skills that can potentially be applied to different sectors. In this sense, Matsusaka (2001) proposes a model with organizational capabilities at its core, defining the diversification strategy as a continuous search process by which companies analyze businesses that are good matches for their organizational skills. However, this model also recognizes that the process of searching for a business that is a good match for organizational capabilities is full of uncertainty and in some cases the uncertainty can only be cleared up by experimenting -entering an area and observing the resultsthat is, through diversification. The model shows how diversification can be a dynamic strategy that maximizes business value and yet multi-segment firms may have a discount relative to specialized firms. It concludes that a mismatch between organizational capabilities and business generates a discount and causes the company to diversify. This suggests that the discount may cause diversification and not vice versa as has been argued in the literature (Campa and Kedia, 2002; Villalonga, 2004a, 2004b).

Previous studies have considered the possibility that sector characteristics may affect the decision to diversify. For example, Campa and Kedia (2002) and Villalonga (2004b) analyze how sectoral characteristics may influence the probability of becoming a diversified company. Similarly, Maksimovic and Phillips (2002) show that sectoral shocks can affect investment decisions of 
conglomerates and specialized companies. However, previous studies do not explicitly consider the possibility that diversified firms may perform better in some places than others, because of their different characteristics. In this sense, Burch, et al. $(2000,2003)$ indicate that the clustering level is negatively related to industry factors of growth opportunities and concentration. In other words, their results imply that the level of clusters increases in sectors facing a reduction in their growth opportunities and their concentration. Basically, if the transaction costs of using the market are high then we could see multi-segment companies; on the other hand, if the costs are low, then we would be seeing competing companies specializing in different sectors (Coase, 1937). Consequently, the number of diversified firms in an industry may increase due to high transaction costs and the existence of economies of scope in the sectors involved (Santalo and Becerra, 2006). This argument has important implications for the explanation of the diversification discount, since the effect of this strategy may not be uniform across all sectors. The fact that a diversified company can create or destroy value depends to some extent on the number of specialized firms competing in the sector or market share. That is, it depends on the intrinsic characteristics of each sector (Santalo and Becerra, 2008). Therefore, one cannot speak of a positive or negative-value business diversification that is maintained across all sectors.

The implementation of diversification involves strategic decisions in a company which are generally linked to investments in real assets. Such investments may affect the potential growth and value of those companies. From this point of view, the Real Options approach has joined the effort to explain the effect of diversification on firm value. The diversification strategy in this approach is defined as "a dynamic and flexible process in which firms exert their growth opportunities, not just for current capture synergies, but also in anticipation of future synergies and complementarities between business lines currently unrelated" (Raynor, 2002). The above arguments are confirmed by the contributions of Bernardo, Chowdhry, and Sernova Palia (2000), who show a positive relationship between real options and the future number of segments in which the company participates. Consequently, the market value of the specialized companies includes the value of their options to diversify and expand into other sectors, while diversified firms have perhaps spent their options to diversify and expand (Bernarndo and Chowdhry, 2002). Indeed, according to the study by Zhao (2008), diversification can lead to low business value for companies that materialize their investment options in real growth, while those who do not exercise their options tend to have above-market values of specialized companies. In this sense, the diversification strategy can be a platform for growth opportunities and a source of flexibility for the company (Andrew and Power, 2004). Considering the arguments of the Real Options approach, it would be inappropriate to speak of a general effect (discount and / or premium) for all types of diversification and attribute this to inefficiency on the part of managers (Zhao, 2008).

Finally, another line of research has emphasized the importance of taking into consideration the age of the company when analyzing the effect of diversification on market value. Companies tend to become more diverse as the years pass and grow, which suggests that some companies are able to redirect resources from business lines with slowing performance, while continuing to benefit from the synergies (Motta, 2003; Gomes and Lividan, 2004). In addition, businesses can expand their business scope in response market pressures in order to survive (Borghesi, Houston and Naranjo, 2007). It is therefore probable that the market value of diversified firms varies over time due to changes in the average age. In this sense, Bernardo and Chowdhry (2002) predict that companies may follow a life cycle, which would start with a specialized project when they are young, to later experiment with a new line of business to learn about their resources (general and specific); if the results are not bad they will undertake to expand over a large number of segments or will specialize again, as during their youth, but increasing their production in the specialized segment. Under this perspective, mature companies that diversify benefit the most in comparison to those young companies, which could see their value reduced considerably when carrying out this 
strategy (Pastor and Veronesi, 2003; Borghesi et al. 2007). Therefore, the diversification strategy may be desirable for certain companies, under certain specific conditions.

In short, the purpose of these new approaches is to provide an explanation for the diversification discount from a more dynamic approach, in which not all companies have to have a negative or positive result, and even this effect does not have to remain in place throughout the life of the company. These studies thus provide a more flexible explanation, according to the specific characteristics of the current changing market.

Table no. 3

Studies on Corporate Diversification

\begin{tabular}{l|l|l}
\hline \multicolumn{1}{c|}{ Discount } & \multicolumn{1}{c|}{ Premium } & Discount and/or Premium \\
\hline Lang \& Stulz (1994) & Khanna \& Palepu (2000) & Markides \& Williamson (1994) \\
Berger \& Ofek (1995) & Whited (2000) & Fluck \& Lynch (1999) \\
Comment \& Jarrell (1995) & Chevalier (2001) & Matsusaka (2001) \\
Servaes (1996) & Campa \& Kedia (2002) & Pástor \& Veronesi (2003) \\
Lamont (1997) & Graham, Lemmon \& Wolf (2002) & Bernardo \& Chowdhry (2006) \\
Shin \& Stulz (1998) & Maksimovic \& Phillips (2002) & Mackey (2006) \\
Lins \& Servaes (1999) & Mansi \& Reeb (2002) & Santalo \& Becerra (2006) \\
\hline
\end{tabular}

Source: The authors

\section{Conclusions}

In the business and finance context it is important to know how to diversify in a responsible way, at least so that in cases in which some of the business activity being carried out does not achieve the expected results, the total investment is not weakened as much as it would have been if only one activity had been chosen. At the present time a large number of firms continue to diversify (for this reason and for others, such as corporate growth) by means of mergers, acquisitions, or the internal development of new product lines. Regardless of the form it takes, the diversification phenomenon continues to be a relevant practice in today's business world, and therefore a topic of great interest not only for academics but also for business professionals themselves.

Nonetheless, research into the diversification strategy, which has been studied for over three decades, has garnered mixed empirical evidence as regards its impact on firm value. The literature reviewed here points to the existence of a complex relationship between diversification and firm value and offers us guidelines as to how to avoid a discount effect. Furthermore, it seems that the research results finding a discount effect of diversification are open to criticism, both when subjected to new filters in the analysis and as regards sample or measurement errors.

With this survey we have attempted to offer some guidelines for action when considering the decision to diversify and to smooth the way for executives and professionals by describing the lessons that the economic literature has provided us with over the years. To do so, we have analyzed the reasons for diversifying or not, describing the costs and benefits deriving from the process and analyzing the discount effect on firm value. Knowing how to diversify responsibly will undoubtedly help managers, shareholders and social and business agents in general to make the best decisions.

As we have seen, the empirical studies regarding the effect of diversification on firm value are numerous and well-documented, but they basically posit two main opposing hypotheses: either the strategy destroys firm value or creates it. In other words, on the one hand there is evidence of a negative relation between firm value and its level of diversification, and on the other there are studies that argue that the relation is positive; that is, that the diversification strategy does not destroy the value of the firms that implement it. Technically, these studies do not question the 
existence of a discount, but rather argue that the discount is a result of factors in the studies such as the databases used, the methodology employed, sectoral differences and the units addressed (singlesegment firms), among other things, as points of reference for comparing firm values.

In our opinion, responsible diversification forces managers to comprehensively evaluate the organizational and financial characteristics of their company. It forces them to reflect on the opportunities for business growth, present and future, to locate the company at the stage of its life cycle, and to analyze the saturation of the sector in relation to specialized companies. It is a more complex picture that cannot be explained under the scope of a single theory. Both growth opportunities and the life cycle of the company may be moderating variables that can help to advance our understanding of the relationship between diversification strategy and firm value from a more dynamic approach. In this perspective, the company would be adapting to its environment through the exercise of its growth opportunities and the challenges presented to it at each stage of its life cycle.

In this respect, some studies analyze in part this new approach; e.g. in Lozano et al. (2013) the authors studied a sample of Spanish firms and concluded that diversified companies with high growth opportunities get a diversification premium in relation to the discount obtained by diversified firms with low growth opportunities. These results allowed them to conclude in general terms, that growth opportunities affect the discount experienced by diversified firms in Spain. The results were robust to the inclusion of several diversification variables. Hence, growth opportunities arose as one of the main firm characteristics which must be controlled in order to evaluate the effect of the diversification strategy on the firm value.

In any case, what does seem to be beyond discussion is that it is ethically wrong to justify diversification only from the perspective of satisfying private gain in the sense that certain agents stand to gain to the detriment of other agents, even when growth is a priority objective for a firm. We therefore recommend analysing a firm and its businesses in depth according to the guidelines described herein so that all the variables needed to make the decision to diversify are taken into consideration, at the same time ensuring that such an action will be positive for its agents and will not damage any others. In this way, the outcomes should lead to value creation not only for the firm but for society at large.

\section{References}

1. Amihud Y, Lev B., 1981. Risk Reduction as a Managerial Motive for Conglomerate Mergers, The Rand Journal of Economics, 12, pp. 605-618

2. Amihud D, Lev B., 1999. Does the Corporate Ownership Structure Affect its Strategy towards Diversification?, Strategic Management Journal, 20, pp. 1063-1069

3. Andres P, Fuente G., 2004. Opciones Reales y Diversificación Corporativa: Evidencia para el caso Español, Cuadernos de Economía y Dirección de la Empresa, 19, pp. 33-54.

4. Barnea A, Logue D., 1973. Stock-Market Based Measures of Corporate Diversification, Journal of Industrial Economics, 51-60.

5. Barney J., 1991. Firm Resources and Sustained Competitive Advantage, Journal of Management, 17 (1), pp.99-129.

6. Baush A, Pils F., 2009. Product Diversification Strategy and Financial Performance: Meta-analytic Evidence on Causality and Construct Multidimensionality, Review of Managerial Science, 3(3), pp. 157-190.

7. Bemheim B, Weston B., 1990. Multimarket Contact and Collusive Behavior, RAND Journal of Economics, 21, pp.1-26.

8. Benito D., 2009. Análisis Teórico de la Relación entre Diversificación Corporativa y Resultados Empresariales, Investigaciones Europeas de Dirección y Economía de la Empresa, 15(2), pp.105126. 
9. Benito D, Guerras L, Zuñiga V., 2012. Four Decades of Research on Product Diversification: A Literature Review, Management Decision, 50(2), pp.324-344.

10. Berger P, Ofek E., 1995. Diversification's Effect on Firm Value, Journal of Financial Economics, 37, pp.39-65.

11. Bernardo A, Chowdhry B, Palia D, Sernova E., 2000. Real Options and Diversification Discount. 4th Annual Real Options Conference, Theory Meets Practice.

12. Bernardo A, Chowdhry B., 2002. Resources, Real Options, and Corporate Strategy, Journal of Financial Economics, 63, pp.211-234.

13. Berry C., 1971. Corporate Growth and Diversification, Journal of Law and Economics, 14, pp.371383.

14. Blume M ., 1971. On the Assessment of Risk, The Journal of Finance, 26(1), pp.1-10.

15. Borghesi R, Houston J, Naranjo A., 2007. Value, Survival, and the Evolution of Firm Organizational Structure, Financial Management, 36(3), pp.5-31.

16. Burch T, Nanda V, Narayanan M., 2003. Industry Structure and Value-motivated Conglomeration, Working paper. University of Miami.

17. Campa J, Kedia S., 2002. Explaining the Diversification Discount, Journal of Finance, 57, pp.17311762.

18. Chandler A., 1977. The Visible Hand, Belknap Press, Cambridge

19. Chandler A., 1990. Scale and Scope: The Dynamics of Industrial Capitalism, Cambridge

20. Chang Y, Thomas H., 1989. The Impact of Diversification Strategy on Risk Return Performance, Strategic Management Journal, 10(3), pp.271-284.

21. Chevalier J., 1999. Why do Firms Undertake Diversifying Mergers? An Examination of the Investment Policies of Merging Firms, Working Paper. University of Chicago.

22. Chevalier J., 20009. What Do We Hnow about Coss-subsidization? Evidence from the Investment Policies of Merging Firms, Working Paper. University of Chicago.

23. Coase R., 1937. The Nature of the Firm, Economica. 4(16), pp.386-405.

24. Comment R, Jarrell G., 1995. Corporate Focus and Stock Returns, Journal of Financial Economics, 37, pp. 67-87.

25. Davis R, Duhaime I., 1992. Diversification, Vertical Integration and Industry Analysis: New Perspectives and Measurements, Strategic Management Journal, 13, pp.511-524.

26. Denis D, Denis D, Sarin A., 1997. Ownership Structure and Top Executive Turnover, Journal of Financial Economics, 45(2), pp.193-221.

27. Denis D, Thothadri B., 1999. Internal Capital Markets, Growth Opportunities, and the Valuation Effects of Corporate Diversification, Working Paper, Purdue University.

28. Doaei M, Ahmad M, Adb N., 2012. Corporate Diversification and Financial Performance: A Review of Literature, Asian Journal of Finance and Accounting, 4(2), pp. 56-74.

29. Fluck Z, Lynch A., 1999. Why do Firms Merge and then Divest? A Theory of Financial Synergy, Journal of Business. 72, pp.319-346.

30. Gomes J, Lividan D., 2004. Optimal Diversification: Reconciling Theory and Evidence, Journal of Finance, 59, pp.507-535.

31. Gort M., 1962. Diversification and Integration in American Industry, National Bureau of Economic Research, Cambridge

32. Graham J, Lemmon M, Wolf J., 2002. Does Corporate Diversification Destroy Value?, Journal of Finance, 57, pp. 695-720.

33. Hall E, John, C., 1994. A Methodological Note on Diversity Measurement, Strategic Management Journal, 15(2), pp.153-168.

34. Hadlock C, Ryngaert M, Thomas S., 2001. Corporate Structure and Equity Offerings: Are there Benefits to Diversification?, Journal of Business, 74, pp.613-635.

35. Harris M, Kriebel C, Raviv A., 1982. Asymmetric information, Incentives and Intrafirm Resource Allocation, Management Science, 20, pp.604-620.

36. Herfindahl O., 1950. Concentration in the US Steel Industry, Doctoral Dissertation Unpublished, ColumbiaUniversity.

37. Hirschman A., 1945. National Power and the Structure of Foreign Trade, Berkeley.

38. Hirschman A., 1964. The Paternity of an Index, The American Economic Review, 54, pp.761-762. 
39. Hoskisson R, Hitt M, Johnson R, Moesel D., 1993. Construct Validity of an Objective Entropy Categorical Measure of Diversification Strategy, Strategic Management Journal, 14, pp.215-235.

40. Huerta P, Navas J., 2007. Análisis de la Relación entre la Diversificación y los Resultados Empresariales: Una Revisión Teórica, Análisis Económico, 49 (XXII), pp.132-148.

41. Hund J, Monk D, Tice S., 2007. Value Creation by Diversified Firms Over Time, Working paper, Available

at

SSRN: http://papers.ssrn.com/sol3/papers.cfm?abstract_id=971155andhttp://scholar.google.es/scholar?q=H und $\% 2 \mathrm{C}+$ Monk $+\mathrm{y}+\mathrm{Tice} \% 2 \mathrm{C}+2007 \% 3 \mathrm{~B}+\mathrm{andbtnG}=\mathrm{andh} \mathrm{l}=\mathrm{esandas} \_\mathrm{sdt}=0 \% 2 \mathrm{C5}$

42. Hund J, Monk D, Tice S., 2010. Rational Learning and the Diversification Discount, Journal of Financial Economics, 96, pp.463-484.

43. Hund J, Monk D, Tice S., 2012. Apples to Apples: The Economic Benefit of Corporate Diversification, Working paper, Available at SSRN: http://papers.ssrn.com/sol3/papers.cfm?abstract_id=2023786andhttp://scholar.google.es/scholar?q= Hund $\% 2 \mathrm{C}+$ Monk $+\mathrm{y}+\mathrm{Tice} \% 2 \mathrm{C}+2007 \% 3 \mathrm{~B}+\mathrm{andbtnG}=\mathrm{andhl}=$ esandas_sdt=0\%2C5

44. Jacquemin C, Berry H., 1979. Entropy Measure of Diversification and Corporate Growth, The Journal of Industrial Economics, 27(4), pp.359-369.

45. Jensen M., 1986. Agency Costs of Free Cash Flow. Corporate Finance, and Takeovers, American Economic Review, 76, pp.323-329.

46. Khanna T, Palepu K., 2000. Is Group Affiliation Profitable in Emerging Markets? An analysis of Diversified Indian Business Groups, Journal of Finance, 55, pp.867-891.

47. Khorana A, Zenner M., 1998. Executive Compensation of Large Acquirers in the 1980's, Journal of Corporate Finance, 4, pp.209-240.

48. Koroshilov Y, Dodonova A., 2005. A dynamic model of diversification and divestiture, Working Paper, available at http://papers.ssrn.com/sol3/papers.cfm?abstract_id=301883.

49. Kuppuswamy V, Serafeim G, Villalonga B., 2012. The Effect of Institutional Factors on the Value of Corporate Diversification, Harvard Business School Accounting and Management Unit Working Paper No. 13-022, available at SSRN: http://ssrn.com/abstract=2132676

50. Lamont O., 1997. Cash Flow and Investment: Evidence from Internal Capital Markets, Journal of Finance, 52, pp.83-110.

51. Lamont O, Polk C., 2002. Does Diversification Destroy Value? Evidence from the Industry Shocks, Journal of Financial Economics, 63, pp.51-77.

52. Lang H, Stulz R., 1994. Tobin's q, Corporate Diversification, and Firm Performance, Journal of Political Economy, 102, pp.1248-1280.

53. Lewellen W., 1971. A Pure Financial Rationale for the Conglomerate Merger, Journal of Finance, 26, pp. 521-537.

54. Linchtenberg F., 1992. Industrial De-diversification and its Consequences for Productivity, Journal Economic Behavior and Organization, 18, pp.427-438.

55. Lins K, Servaes H., 1999. International Evidence on the Value of Corporate Diversification, Journal of Finance, 54, pp.2215-2239.

56. Lins K, Servaes H., 2002. Is Corporate Diversification Beneficial in Emerging Markets?, Financial Management, 31(2), pp.5-31.

57. Lozano B, Miguel A, Rios D., 2013. Corporate Diversification and Growth Opportunities: Evidence for the Spanish Market, Revista Española de Fnanciación y Contabilidad, Forthcoming.

58. Mackey T., 2006. Essays on Corporate Diversification and Firm Value, PhD Dissertation, School of the Ohio State University.

59. Majd S, Myers S., 1987. Tax Asymmetries and Corporate Income Tax Reform, Journal of Financial Economics, 12, pp.147-175.

60. Maksimovic V, Phillips G., 2002. Do Conglomerate Firms Allocate Resources Inefficiently across Industries? Theory and Evidence, Journal of Finance. 57, pp.721-767.

61. Mansi S, Reeb D., 2002. Corporate Diversification: What gets Discounted?, Journal of Finance, 57, pp. 2167-2183.

62. Markides C, Williamson P., 1994. Related Diversification, Core Competencies and Corporate Performance, Strategic Management Journal, Summer Special Issue 15, pp.149-165. 
63. Markides C, Williamson P., 1996. Corporate Diversification and Organizational Structure: A Resource-based View, Academy of Management Journal, 39(2), pp.340-367.

64. Markowitz H., 1952. Portfolio Selection, The Journal of Finance, 7(1), pp.77-91.

65. Martin J, Sayrak A., 2003. Corporate Diversification and Shareholder Value: A survey of Recent Literature, Journal of Corporate Finance, 9, pp.37-57.

66. Matsusaka J., 2001. Corporate Diversification, Value Maximization, and Organizational Capabilities, Journal of Business, 74(3), pp.409-431.

67. Meyer M, Milgrom P, Roberts J., 1992. Organizational Prospects, Influence Costs, and Ownership Changes, Journal of Economics and Management Strategy, 1, pp.9-35.

68. Montgomery C., 1994. Corporate Diversification, Journal of Economic Perspectives, 8, pp.163-178.

69. Montgomery C., 1982. The Measurement of Firm Diversification: Some New Empirical Evidence, Academy of Management Journal. 25(2), 299-307.

70. Morck R, Shleifer A, Vishny R., 1990. Do Managerial Objectives Drive Bad Acquisitions?, Journal of Finance, 45, pp.31-48.

71. Nayyar P., 1992. Performance Effects of Three Foci in Service Firms, Academy of Management Journal, 35(5), pp.985-1009.

72. Palepu K., 1985. Diversification Strategy, Profit Performance and the Entropy Measure, Strategic Management Journal, 6(3), pp.239-255.

73. Pastor L, Veronesi P., 2003. Stock Valuation and Learning about Profitability, The Journal of Finance, 58(5), pp.1749-1790.

74. Pitts R, Hopkins H., 1982. Firm Diversity: Conceptualization and Measurement, Academy of Management Review, 7(4), pp.620-629.

75. Rajan R, Servaes H, Zingales L., 2000. The Cost of Diversity: The Diversification Discount and Inefficient Investment, Journal of Finance, 55, pp.35-80.

76. Ramanujam V, Varadarajan P., 1989. Research on Corporate Diversification: A Synthesis, Strategic Management Journal, 10(6), pp.523-551.

77. Raynor M., 2002. Diversification as Real Options and the Implications on Firm-Specific Risk and Performance, The Engineering Economist, 4(4), pp.371-389.

78. Rumelt R., 1974. Strategy, Structure and Economic Performance, HarvardUniversity Press, Cambridge

79. Sambharya R., 2000. Assessing the Construct Validity of Strategic and SIC-based Measures of Corporate Diversification, British Journal of Management, 11, pp.163-173.

80. Santalo J, Becerra M., 2006. The Dominance of Diversified versus Specialized Firm across Industries, Journal of Business Research, 59(3), pp.335-340.

81. Santalo J., Becerra M., 2008. Competition from Specialized Firms and the DiversificationPerformance Linkage, The Journal of Finance, 63 (2), pp. 851-883.

82. Scharfstein D. S., Stein J. C., 2000, The Dark Side of Internal Capital Markets: Divisional RentSeeking and Inefficient Investment, Journal of Finance, 55, pp. 2537-2564.

83. Servaes H., 1996. The Value of Diversification during the Conglomerate Merger Wave, Journal of Finance, 51, pp. 1201-1225.

84. Sharpe W. F., 1966. Mutual Fund Performance, Journal of Business, January, 119-138

85. Sharpe W.F., 1964. Capital Asset Prices: A Theory of Market Equilibrium under Conditions of Risk, Journal of Finance, 19, pp.425-442.

86. Shin H., Stulz R.., 1998. Are Internal Capital Markets Efficient?, The Quarterly Journal of Economics, 113 (2), pp. 531-552.

87. Shleifer A., Vishny R., 1989. Management Entrenchment: The Case of Manager-Specific Investments, Journal of Financial Economics, 25, pp. 123-139.

88. Smith K.V., Schreiner J.C., 1969. A Portfolio Analysis of Conglomerate Diversification, Journal of Finance, 24, pp. 413-427.

89. Stein J., 1997. Internal Capital Markets and the Competition for Corporate Resources, Journal of Finance, 52, pp. 111-133.

90. Stulz R., 1990. Managerial Discretion and Optimal Financing Policies, Journal of Financial Economics, 26, pp. 3-27. 
91. Suárez I., 1994. Estrategia de Diversificación y Resultados de la Empresa Española, Revista de Economía Aplicada, 11, pp. 103-128.

92. Tirole J., 1995. The Theory of Industrial Organization, MIT Press, Cambridge

93. Varadarajan P. Y., Ramanujan V., 1987. Diversification and Performance: A Reexamination Using a New Two-dimensional Conceptualization of Diversity in Firms, The Academy of Management Journal, 30 (2), pp. 380-393.

94. Villalonga B., McGahan A. M., 2005. The Choice among Acquisitions, Alliances, and Divestitures, Strategic Management Journal, 26 (13), pp. 1183-1208.

95. Villalonga B., 2004a. Diversification Discount or Premium? Evidence from the Business Information Tracking Series, Journal of Finance, 59, pp. 479-506.

96. Villalonga B., 2004b. Does Diversification Cause the Diversification Discount?, Financial Management, 33, pp. 5-27.

97. Wan W., Hoskisson R., Short J., Yiu D., 2011. Resource-Based Theory and Corporate Diversification: Accomplishments and Opportunities, Journal of Management, 37 (5), pp. 13351368.

98. Weston J., 1970. The Nature and Significance of Conglomerate Firms', St. John's Law Review, 44, pp. 66-80.

99. Whited T., 2001. Is it Inefficient Investment that Causes the Diversification Discount?, Journal of Finance, 56, pp. 1667-1691.

100. Williamson O., 1985. The Economic Institutions of Capitalism, Free Press, New York.

101. Wood A., 1971. Diversification, Merger and Research Expenditures: A Review of Empirical Studies, In R Martis, A Wood. (Eds)., The Corporate Economy: Growth Competition and Innovative Potential, Boston, Harvard University Press.

102. Wrigley L., 1970. Divisional Autonomy and Diversification, [Unpublished Doctoral Thesis], Boston, Harvard Business School.

103. Zhao H., 2008. Diversification Effects: A Real Options Approach, [Unpublished Doctoral Thesis], Kent State University. 